\title{
Penambahan agar-agar dan pengaruhnya terhadap kestabilan dan daya terima susu tempe pada mahasiswa Politeknik Kesehatan Jurusan Gizi Yogyakarta ${ }^{1}$
}

Isti Suryani², Agus Santoso ${ }^{3}$, M. Juffrie ${ }^{4}$

\begin{abstract}
Background: The production of tempeh milk is an effort to diversify tempeh-based food processing potential as functional food. However, as vegetable milk tempeh milk has the disadvantages of tasting bitter and being easily precipitate. The addition of gelatine is potential as stabilizer that is expected to counter the disadvantages and improve the taste of tempeh milk.

Objective: To identify the effect of gelatine addition to stability and acceptability of tempeh milk among students of Nutrition Department of Health Polytechnic Yogyakarta.

Method: The study was experimental with a completely randomized design, comprising four experiments, i.e. tempeh milk with gelatine addition as much as $2 \%, 3 \%, 4 \%$ and no gelatine addition as control. Organoleptic test was made by 25 skilled panelist, students of Nutrition Department of Health Polytechnic Yogyakarta, to identify acceptability of tempeh milk. Whereas viscocity test and visual observation through the assessment of tempeh milk precipitation level within 5 hours storage were made to identify emulsion stability. Data analysis used Anova and Duncan advanced test.

Result: Stable emulsion could be achieved through gelatine addition of $2 \%$ at emulsion consistency $89.10 \%$, viscocity 0.225 poise. Better emulsion stability was achieved through gelatine addition of $3 \%$ at emulsion consistency $91.10 \%$, viscocity 0.249 poise. Best emulsion stability was achieved through gelatine addition of $4 \%$ at emulsion consistency $95.58 \%$, viscocity 0.254 poise and lowest emulsion stability was found in the control without gelatine addition at emulsion consistency $80.84 \%$, viscocity 0.216 poise. The result of proximate nutrition value of tempeh milk with gelatine addition $4 \%$ (most stable) were energy $55.54 \mathrm{cal}$, protein $2.14 \mathrm{gr}$, fat $1.82 \mathrm{~g}$, carbohydrate $7.65 \%$, water $86.23 \mathrm{~g}$, ash $0.15 \%$ and raw fibre $2.01 \%$.

Conclusion: There was no effect of gelatine addition at various concentration to acceptability of tempeh milk. There was effect of gelatine addition at various concentration to stability of tempeh milk. The highest emulsion stability was achieved in tempeh milk with gelatine addition of $4 \%$.
\end{abstract}

KEY WORDS emulsion stability, acceptability, tempeh milk, gelatine

\section{PENDAHULUAN}

Penelitian dasar mengenai tempe dalam kurun waktu 25 tahun terakhir cepat berkembang di luar negeri, terutama Amerika dan Jepang. Namun di Indonesia sebagai negeri asalnya, harkat atau persepsi nilai sosial tempe belum dihargai sebagaimana mestinya (1). Padahal tempe terbukti baik untuk kesehatan, seperti mempunyai efek menurunkan level lipid yang berhubungan dengan kolesterol, menurunkan gejala negatif pada massa menopause (menopausal symptoms), serta mempunyai potensi untuk pencegahan kanker (2).

Penelitian yang dilakukan di Indonesia menunjukkan bahwa penggunaan tempe dalam makanan sehari-hari akan mencegah beberapa morbiditas penyakit seperti penyakit saluran cerna dan mukosa. Sedangkan penelitian yang menggunakan tempe sebagai bahan nutrisi pada penderita diare menunjukkan bahwa pada kelompok pasien diare yang menerima bubur tempe sembuh lebih cepat dibanding yang tidak menerima bubur tempe (3). Namun penelitian di RS Sardjito Yogyakarta menunjukkan bahwa daya terima bubur tempe lebih rendah dibanding bubur nasi dan bahan makanan campuran pada anak penderita diare umur 6-30 bulan (4).
Sebenarnya potensi tempe sebagai bahan makanan menyehatkan dan bergizi tinggi sudah banyak diketahui, tetapi nilai sosial tempe masih dianggap rendah sehingga pengembangan industri tempe kurang mendapat perhatian dari masyarakat dan pemerintah. Pembuatan susu tempe merupakan upaya penganekaragaman makanan berbahan dasar tempe, selain meningkatkan citra tempe sebagai warisan nenek moyang bangsa Indonesia yang sangat berharga. Susu tempe dapat digolongkan minuman fungsional karena kandungan zat bioaktifnya yang tinggi.

Selama ini tempe masih dikenal sebagai makanan tradisional yang harus segera diolah karena mudah rusak.

\footnotetext{
${ }_{1}^{1}$ Dipresentasikan pada International Dietetic Update pada tanggal 1517 Oktober 2009 di Yogyakarta kerjasama dengan Asosiasi Dietisien Indonesia, Jurnal Gizi Klinik Indonesia, dan Prodi Gizi Kesehatan FKUGM serta didanai oleh Pendidikan Tinggi Kementerian Pendidikan Nasional.

2 Jurusan Gizi Politeknik Kesehatan Kementerian Kesehatan RI, Jl. Tatabumi No 3 Yogyakarta

${ }^{3}$ Instalasi Gizi RSUP Dr. Sardjito Yogyakarta, e-mail: santosoagus31@ yahoo.com

${ }^{4}$ Instalasi Kesehatan Anak RSUP Dr. Sardjito Yogyakarta, Jl.Kesehatan, Yogyakarta, e-mail: juffrie@indosat.net.id
} 
Sebenarnya dengan sudah diketahuinya efek positif bagi tubuh dan kandungan nutrisi yang kompleks, tempe dapat dikembangkan menjadi produk generasi kedua. Salah satu produk generasi kedua tempe adalah dengan memproses menjadi susu tempe. Susu tempe perlu distabilkan supaya produk ini tidak mudah rusak dan tidak mudah mengendap.

Sebagai susu nabati, susu tempe mempunyai kelemahan adanya rasa pahit dan mudah mengendap, sehingga supaya susu tempe dapat diterima dengan baik, diperlukan suatu teknik pengolahan yang dapat mengurangi kelemahan tersebut. Salah satunya dengan upaya menambahkan agar-agar yang mempunyai potensi sebagai bahan makanan pengelmusi. Rasa pahit dapat disebabkan oleh berbagai ragam senyawa organik dan anorganik, banyak senyawa dari tumbuhan berasa pahit dan kepekaan indera manusia lebih sensitif terhadap adanya rasa pahit daripada rasa lainnya (5). Senyawasenyawa kedelai yang mempunyai rasa pahit, seperti maltol dan asam-asam palmitat, stearat, oleat, linoneat dan linolenat juga masih dijumpai dalam tempe (1).

Agar-agar merupakan ekstrak dari rumput laut yang memiliki karakteristik unik karena memiliki daya ikat terhadap air, pada suhu $39^{\circ} \mathrm{C}$ agar-agar akan memadat membentuk gel dan pada suhu $80^{\circ} \mathrm{C}$ akan mencair. Bagian utama dari rumput laut merah dan rumput laut coklat adalah phycocolloid yang merupakan polisakarida kompleks yang larut air dan akan membentuk sistem koloid ketika dilarutkan dalam air. Ekstrak koloid dari rumput laut (alginate, agar-agar, dan karagenan) mempunyai kompabilitas yang tinggi yaitu mampu menyatu dengan bahan-bahan lain. Dengan kompabilitas yang tinggi serta sifat dari agar-agar yang akan membentuk gel pada suhu kamar dan mudah menyerap air maka agar-agar banyak dimanfaatkan sebagai pembentuk emulsi, stabiliser, zat pensuspensi, dan pengental (5). Agar-agar merupakan pembentuk gel sangat kuat, karena pembentukan gel sudah dapat teramati pada konsentrasi 0,04\% (6).

Proses fermentasi yang dilakukan terhadap biji kedelai dalam pembuatan tempe, tidak hanya mampu meningkatkan nilai gizinya saja, tetapi nilai biologis dan Protein Efficiency Ratio (PER) tempe lebih tinggi dibanding tidak difermentasi (7).

Penelitian terkait dengan susu tempe yaitu penelitian yang dilakukan Lembaga IImu Pengetahuan Indonesia (LIPI) tentang alternatif pati jagung termodifikasi sebagai pengental dan penstabil serta pengaruhnya terhadap kualitas susu tempe secara hidrolis enzimatik (8). Penelitian tersebut bertujuan untuk mengetahui pengaruh konsentrasi dan jenis penstabil pati jagung termodifikasi melalui cross linking pada suhu proses berbeda terhadap karakteristik susu tempe dari hidrolisat tempe dengan perlakuan optimal, sehingga diperoleh susu tempe dengan kandungan nutrisi terbaik dan kestabilan emulsi tetap. Hasil penelitian menunjukkan bahwa proses hidrolisis enzimatik dengan crude papain dapat menaikkan kandungan protein, protein terlarut, $\mathrm{N}$-amini, dan kestabilan sebelum hidrolisis serta setelah hidrolisis.

Berdasarkan latar belakang tersebut, maka penelitian ini bertujuan untuk mengetahui pengaruh penambahan agar-agar terhadap kestabilan dan daya terima susu tempe pada Mahasiswa Politeknik Kesehatan Jurusan Gizi Yogyakarta.

\section{BAHAN DAN METODE}

Jenis penelitian adalah eksperimental dengan Rancangan Acak Lengkap (RAL) (9) terdiri 4 perlakuan, yaitu penambahan agar-agar $2 \%, 3 \%, 4 \%$, dan tanpa penambahan agar-agar sebagai kontrol. Waktu penelitian adalah bulan Agustus 2007. Pembuatan susu tempe dilaksanakan di Laboratorium IImu Teknologi Pangan Politeknik Kesehatan Jurusan Gizi Yogyakarta. Uji organoleptik dilaksanakan di Laboratorium Uji Organoleptik Politeknik kesehatan Jurusan Gizi Yogyakarta dan analisis zat gizi dilaksanakan di Laboratorium Gizi Jurusan Teknologi Pangan dan Hasil Pertanian UGM.

Kestabilan emulsi diketahui berdasarkan konsistensi emulsi dan viskositas. Konsistensi emulsi dilakukan dengan cara pengamatan visual dengan mencatat tingkat pengendapan susu tempe selama 5 jam penyimpanan. Kestabilan emulsi yang tetap ditunjukkan dengan tercapainya konsistensi emulsi lebih dari $80 \%$ selama 5 jam penyimpanan. Pada susu tempe yang mempunyai kestabilan emulsi paling stabil dilakukan analisis nilai gizi proksimat, yaitu terdiri dari analisis kadar air, kadar abu, kadar protein, dan kadar serat kasar. Kemudian dibandingkan dengan nilai gizi susu kedelai, susu sapi, dan Air Susu Ibu (ASI), nilai gizi pembanding diperoleh dari Direktorat Gizi Departemen Kesehatan RI tahun 2003 (10). Uji viskositas dilakukan dengan menggunakan alat stormer viscosimeter dengan satuan poise.

Untuk mengetahui daya terima susu tempe dilakukan uji organoleptik dengan panelis terlatih sebanyak 25 orang yang merupakan mahasiswa Politeknik Kesehatan Jurusan Gizi Yogyakarta, dengan parameter penilaian: sangat suka, suka, agak suka, tidak suka, sangat tidak suka, dengan skor berturut-turut sebesar 5, 4, 3, 2, dan 1. Daya terima meliputi rasa, aroma dan kekentalan. Semakin tinggi skor rata-rata penilaian yang diberikan panelis berarti susu tempe semakin disukai atau daya terima semakin tinggi, demikian juga sebaliknya.

Variabel bebas adalah penambahan agar-agar pada susu tempe. Variabel tergantung adalah kestabilan, daya terima susu tempe dan analisis zat gizi. Analisis data menggunakan uji statistik program software komputer: Anova untuk mengetahui ada tidaknya perbedaan pengaruh perlakuan dan apabila antara sampel ada 
perbedaan, maka untuk mencari sampel mana yang saling berbeda dianalisis dengan uji lanjutan Duncan New Multiple Range Test.

\section{HASIL DAN BAHASAN}

\section{Kestabilan susu tempe}

Konsistensi emulsi. Pengamatan secara visual dilakukan dengan menyimpan keempat sampel susu tempe dalam gelas ukur selama 5 jam pada suhu kamar dan kemudian setiap 1 jam diamati laju pengendapannya. Analisis anova menunjukkan ada perbedaan bermakna dalam laju pengendapan dengan p-value sebesar 0,01, di mana dapat disimpulkan bahwa ada perbedaan pengaruh yang signifikan penambahan agar-agar dengan berbagai konsentrasi terhadap tingkat kestabilan susu tempe. Karena dengan analisis uji anova didapatkan ada perbedaan yang nyata maka untuk mencari sampel mana yang saling berbeda dianalisis dengan uji lanjutan Duncan New Multiple Range Test, seperti terlihat pada Tabel 1.

Tabel 1. Pengaruh penambahan agar-agar terhadap konsistensi emulsi susu tempe

\begin{tabular}{lc}
\hline $\begin{array}{c}\text { Konsentrasi penambahan agar- } \\
\text { agar }\end{array}$ & $\begin{array}{c}\text { Konsistensi emulsi } \\
(\%)\end{array}$ \\
\hline $\begin{array}{l}\text { Tanpa penambahan agar-agar } \\
\text { (kontrol) }\end{array}$ & $80,840^{\mathrm{a}}$ \\
Penambahan agar-agar 2\% & \\
Penambahan agar-agar 3\% & $89,100^{\mathrm{b}}$ \\
Penambahan agar-agar 4\% & $91,100^{\mathrm{bc}}$ \\
\hline
\end{tabular}

Keterangan: Huruf yang sama menunjukkan tidak ada perbedaan nyata.

Hasil uji Duncan New Multiple Range Testmenunjukkan konsistensi emulsi susu tempe tanpa penambahan agaragar (kontrol) berbeda nyata dengan susu tempe dengan penambahan agar-agar $2 \%, 3 \%$ dan $4 \%$. Susu tempe dengan penambahan agar-agar $2 \%$ berbeda nyata dengan kontrol dan susu tempe dengan penambahan agar-agar $4 \%$ tetapi tidak berbeda nyata dengan susu tempe dengan penambahan agar-agar $3 \%$. Susu tempe dengan penambahan agar-agar $3 \%$ berbeda nyata dengan kontrol, tetapi tidak berbeda nyata dengan susu tempe dengan penambahan agar-agar $2 \%$ dan $4 \%$. Sedangkan susu tempe dengan penambahan agar-agar $4 \%$ berbeda nyata dengan kontrol, dan susu tempe dengan penambahan agar-agar $2 \%$, tetapi tidak berbeda nyata dengan susu tempe dengan penambahan agar-agar $3 \%$.

Gambar 1 menunjukkan bahwa susu tempe dengan penambahan agar-agar $2 \%, 3 \%$ dan $4 \%$ mempunyai konsistensi emulsi yang stabil pada penyimpanan selama 5 jam yaitu di atas $80 \%$. Konsistensi emulsi yang paling stabil ditunjukkan oleh susu tempe dengan penambahan agar-agar $4 \%$, yaitu pada penyimpanan 1 jam didapatkan konsistensi emulsi sebesar $97,8 \%$,

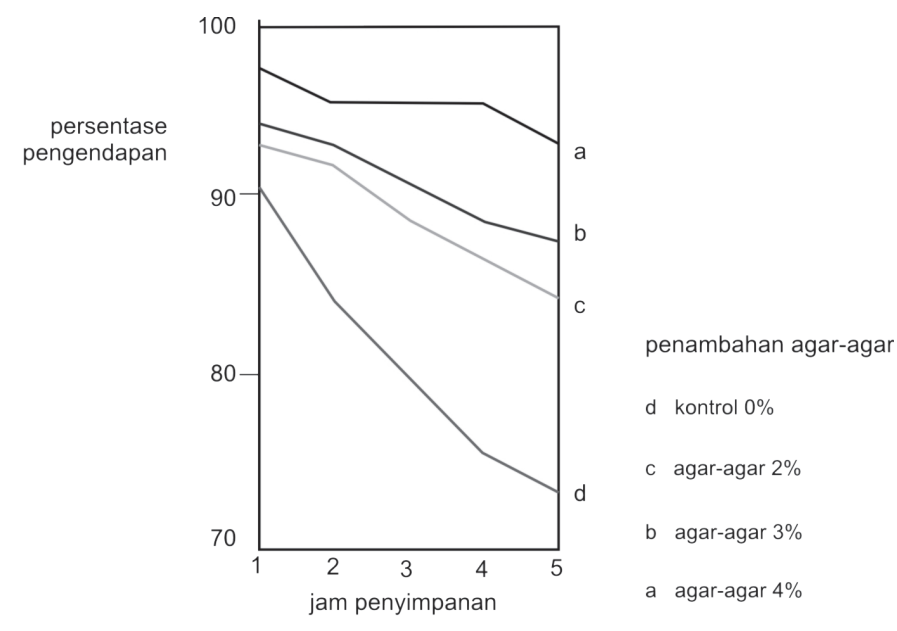

Gambar 1. Pengaruh penambahan agar-agar terhadap konsistensi emulsi susu tempe

pada 2 jam penyimpanan konsistensi emulsi cenderung stabil sampai pada 4 jam penyimpanan dengan tingkat kestabilan $95,6 \%$. Pada 4 jam penyimpanan konsistensi emulsi mulai bergerak turun sampai didapat tingkat kestabilan $93,3 \%$ pada penyimpanan 5 jam. Sedangkan susu tempe tanpa penambahan agar-agar (kontrol) mempunyai konsistensi emulsi yang paling tidak stabil dengan ditunjukkan garis pada gambar di atas yang turun dengan tajam, yang berarti penurunan konsistensi emulsi berjalan dengan cepat. Pada penyimpanan 1 jam masih didapatkan konsistensi emulsi yang baik (91\%) tetapi mulai penyimpanan 3 jam didapatkan konsistensi emulsi yang tidak stabil $(<80 \%)$ dan pada akhirnya pada penyimpanan 5 jam hanya didapatkan konsistensi emulsi sebesar $73,3 \%$. Berbeda dengan hasil penelitian di Pusat Penelitian Kimia Lembaga IImu Pengetahuan Indonesia (LIPI) tahun 2009, bahwa susu tempe dengan konsentrasi penstabil pati jagung 0,25\% menunjukkan konsistensi emulsi tertinggi $(84,03 \%)$ pada penyimpanan selama 5 jam. Hal ini disebabkan berbedanya penstabil yang digunakan, yaitu agar-agar dan pati jagung. Konsistensi emulsi susu tempe dengan penstabil pati jagung lebih rendah daripada agar-agar karena pati jagung memiliki rantai amilosa dan amilopektin yang panjang sehingga memungkinkan terjadinya retrogradasi dan sineresis yang menyebabkan terjadinya ketidakstabilan emulsi karena penurunan viskositas (7).

Viskositas. Pada pengujian viskositas menggunakan alat stormer viscosimeter, menunjukan viskositas tertinggi dimiliki oleh susu tempe dengan penambahan agar-agar $4 \%$ yaitu 0,254 poise dan susu tempe tanpa penambahan agar-agar (kontrol) menunjukkan viskositas yang paling rendah yaitu 0,216 poise, seperti terlihat pada Tabel 2.

Agar-agar merupakan polisakarida yang dapat menghasilkan larutan yang sangat kental dan merupakan pembentuk gel yang paling kuat karena pembentukan gel sudah dapat teramati pada konsentrasi rendah yaitu $0,04 \%$. 


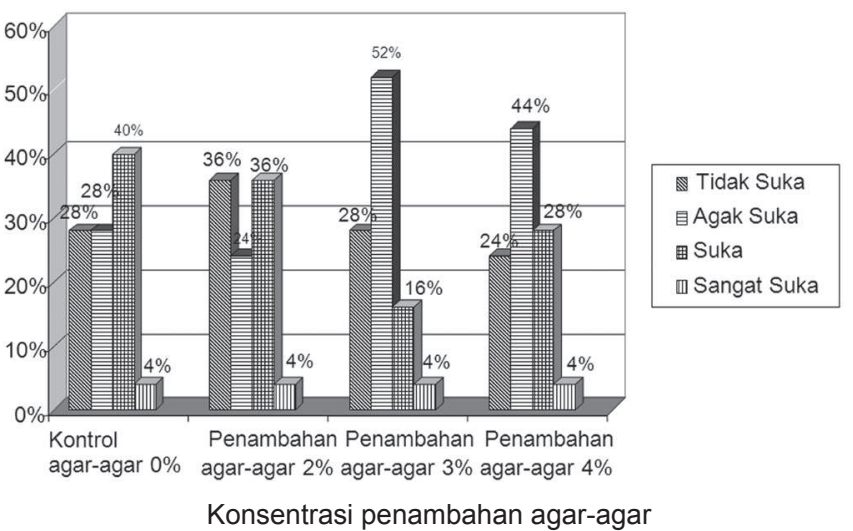

Gambar 2. Tingkat kesukaan panelis terhadap rasa susu tempe

Tabel 2. Hasil pengukuran viskositas susu tempe

\begin{tabular}{lc}
\hline Konsentrasi penambahan agar-agar & Viskositas (poise) \\
\hline Tanpa penambahan agar-agar (kontrol) & 0,216 \\
Penambahan agar-agar 2\% & 0,225 \\
Penambahan agar-agar 3\% & 0,249 \\
Penambahan agar-agar 4\% & 0,254 \\
\hline
\end{tabular}

Agar-agar mempunyai sifat histeresis yaitu pembentukan gel terjadi pada suhu jauh di bawah suhu leleh-gel (5).

Hasil pengamatan visual dan pengujian viskositas menunjukkan bahwa konsistensi emulsi paling stabil dimiliki oleh susu tempe dengan penambahan agaragar $4 \%$ kemudian diikuti dengan susu tempe dengan penambahan agar-agar $3 \%, 2 \%$, dan susu tempe tanpa penambahan agar-agar (kontrol) mempunyai konsistensi emulsi yang paling rendah, sehingga dapat disimpulkan bahwa semakin tinggi konsentrasi penambahan agar-agar dapat membuat susu tempe mempunyai konsistensi emulsi yang semakin stabil.

\section{Daya terima}

Rasa. Rasa merupakan faktor yang penting di samping tekstur, warna, dan aroma yang akan mempengaruhi cita rasa dari suatu produk olahan makanan. Penerimaan seseorang terhadap suatu produk makanan banyak dipengaruhi oleh rasa yang ditimbulkan dari produk tersebut. Rasa suatu pangan dapat berasal dari sifat bahan baku itu sendiri atau berasal dari penambahan zat lain pada proses pengolahannya.

Pada dasarnya bahan pangan tidak hanya terdiri dari salah satu rasa, tetapi merupakan gabungan dari berbagai macam rasa secara terpadu sehingga menimbulkan cita rasa yang utuh. Pengamatan cita rasa selain merupakan penilaian indera pengecap juga banyak dipengaruhi oleh indera-indera yang lain, seperti indera penglihatan, pembauan, pendengaran, dan perabaan (11).

Tingkat kesukaan panelis terhadap rasa susu tempe dari keempat sampel yang disajikan, penilaian tertinggi pada setiap sampel adalah: pada kontrol sebanyak $40 \%$ panelis menyukai rasa susu tempe, pada susu tempe dengan penambahan agar-agar $2 \%$ masing-masing sebanyak $36 \%$ panelis tidak menyukai dan menyukai rasa susu tempe, pada susu tempe dengan penambahan agaragar $3 \%$ dan $4 \%$ berturut-turut sebanyak $52 \%$ dan $44 \%$ panelis agak menyukai rasa susu tempe (Gambar 2).

Tempe sebenarnya lebih disukai daripada kedelai, tetapi bagi masyarakat Indonesia yang sudah terbiasa mengonsumsi tempe masih sulit untuk mendeskripsikan rasa tempe. Jika mereka diminta untuk mendeskripsikan rasa makanan yang terbuat dari tempe, kebanyakan hanya dapat mengatakan bahwa ada "rasa tempe". Beberapa panelis memberikan catatan pada formulir uji organoleptik bahwa adanya rasa pahit pada susu tempe. Rasa pahit pada makanan dapat disebabkan oleh berbagai ragam senyawa organik dan anorganik, banyak senyawa dari tumbuhan berasa pahit dan kepekaan indera manusia lebih sensitif terhadap adanya rasa pahit daripada rasa lainnya (3). Menurut Yoshida yang disitasi De Man, pada tempe ditemukan profil flavour yang karakteristiknya berbeda dengan flavour kedelai yang berubah-ubah profilnya jika kondisi fermentasi juga diubah (3). Beberapa di antaranya yang penting adalah diaetil, asetoin 2,3 butandiol, asam ivalerat dan senyawa-senyawa derivate piridin. Senyawasenyawa kedelai yang mempunyai rasa pahit, seperti maltol dan asam-asam palmitat, stearat, oleat, linoneat dan linolenat juga masih dijumpai dalam tempe.

Tabel 3. Analisis tingkat kesukaan panelis terhadap rasa susu tempe

\begin{tabular}{lcccc}
\hline \multicolumn{1}{c}{ Variabel } & Panelis & Rerata & F & P \\
& & & & \\
\hline Tanpa penambahan agar- & 25 & 3,20 & & \\
agar (kontrol) & & & & \\
Penambahan agar-agar 2\% & 25 & 3,08 & 0,230 & 0,876 \\
Penambahan agar-agar 3\% & 25 & 3,00 & & \\
Penambahan agar-agar 4\% & 25 & 3,12 & & \\
\hline
\end{tabular}

Pada Tabel 3 diperlihatkan tingkat kesukaan panelis terhadap rasa susu tempe mempunyai skor antara 3,00 sampai dengan 3,20 . Skor tertinggi dimiliki oleh susu tempe tanpa penambahan agar-agar (kontrol), yang berarti panelis lebih menyukai rasa susu tempe tanpa penambahan agar-agar daripada susu tempe lainnya. Hasil uji statistik menggunakan analisis anova menunjukkan bahwa nilai $F$ hitung adalah 0,230 dengan P-value 0,876 dapat disimpulkan bahwa tidak ada pengaruh yang nyata penambahan agar-agar dengan berbagai konsentrasi terhadap daya terima rasa susu tempe. Hal ini disebabkan karena selain agar-agar yang ditambahkan pada susu tempe mempunyai rasa yang netral, juga konsentrasi penambahan agar-agar yang rendah menyebabkan agaragar yang ditambahkan tidak mengubah rasa dasar dari susu tempe. 
Aroma. Aroma atau bau-bauan dapat didefinisikan sebagai sesuatu yang dapat diamati dengan indera penciuman. Agar dapat ditangkap oleh indera penciuman, zat-zat aroma harus dapat menguap, sedikit larut dalam air dan sedikit larut dalam lemak. Dalam pengujian aroma lebih kompleks daripada pengujian terhadap rasa, karena penilaian aroma atau bau suatu produk akan memberikan nilai yang baik dengan cara membau maupun dengan merasakan. Seringkali penilaian aroma lebih kuat diamati dengan merasakan dengan indera pengecap daripada dengan indera penciuman (12).

Susu tempe yang dihasilkan mempunyai aroma khas tempe yang mungkin bagi sebagian panelis masih sulit untuk dideskripsikan. Tingkat kesukaan panelis terhadap aroma susu tempe dari keempat sampel yang disajikan, sebagian besar sama-sama pada tingkat suka, kecuali pada penambahan agar-agar $3 \%$ yang sama-sama pada tingkat agak suka dan suka yaitu sebesar 44\% (Gambar 3).

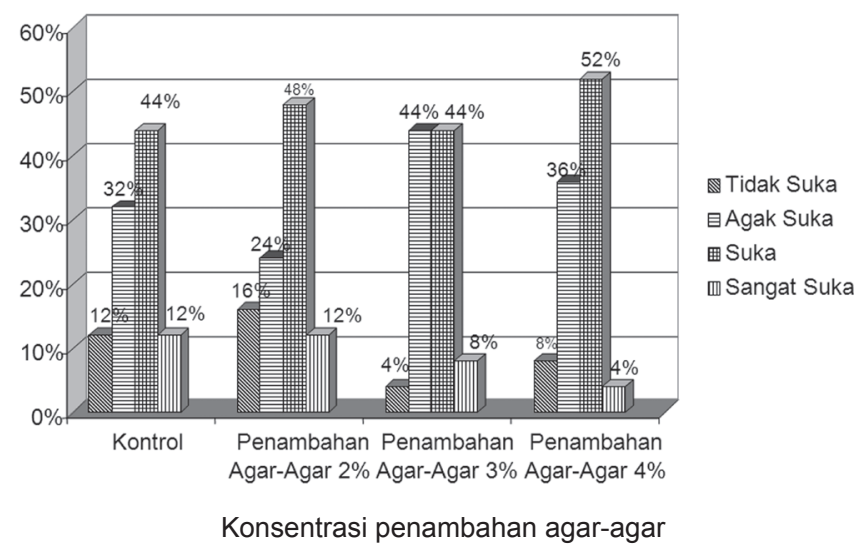

Gambar 3. Tingkat kesukaan panelis terhadap aroma susu tempe

Tabel 4. Analisis tingkat kesukaan panelis terhadap aroma susu tempe

\begin{tabular}{lcccc}
\hline \multicolumn{1}{c}{ Variabel } & Panelis & Rerata & F & P \\
\hline Tanpa penambahan agar- & 25 & 3,56 & & \\
agar (kontrol) & & & & \\
Penambahan agar-agar 2\% & 25 & 3,56 & 0,015 & 0,997 \\
Penambahan agar-agar 3\% & 25 & 3,56 & & \\
Penambahan agar-agar 4\% & 25 & 3,52 & & \\
\hline
\end{tabular}

Pada Tabel 4 tingkat kesukaan panelis terhadap aroma mempunyai skor antara 3,52 sampai dengan 3,56 . Susu tempe dengan penambahan agar-agar $0 \%$, $2 \%$, dan $3 \%$ mempunyai skor penilaian yang sama dan tertinggi yaitu 3,56 , yang berarti panelis mempunyai tingkat kesukaan yang sama terhadap ketiga aroma susu tempe tersebut. Ketiga aroma susu tempe tersebut juga lebih disukai daripada aroma susu tempe dengan penambahan agar-agar 4\%. Hasil uji statistik menggunakan analisis anova menunjukkan bahwa $\mathrm{F}$ hitung adalah 0,015 dengan $p$-value 0,997 . Karena $p$-value lebih dari 0,05 maka dapat disimpulkan bahwa tidak ada pengaruh yang nyata penambahan agar-agar dengan berbagai konsentrasi terhadap daya terima aroma susu tempe.

Kekentalan. Tekstur merupakan bagian yang penting dari mutu makanan, kadang-kadang lebih penting daripada rasa, aroma, dan warna sehingga tekstur ikut mempengaruhi citarasa dari suatu produk makanan (3). Beberapa panelis mengungkapkan bahwa tingkat kekentalan keempat sampel susu tempe sulit dibedakan, hal ini dikarenakan perbedaan konsentrasi penambahan agar-agar terlalu kecil sehingga secara fisik perbedaan tingkat kekentalan pada susu tempe dengan penambahan agar-agar $0 \%, 2 \%, 3 \%$, dan $4 \%$ sulit diamati. Tingkat kesukaan panelis terhadap kekentalan susu tempe dari keempat sampel yang disajikan, penilaian tertinggi pada setiap sampel adalah sama-sama pada tingkat suka, yang membedakan hanyalah persentasenya yaitu yang tertinggi $(72 \%)$ diperoleh pada penambahan agar-agar $3 \%$, diikuti oleh penambahan agar-agar $4 \%, 2 \%$, dan kontrol (berturutturut sebesar $52 \%$, $48 \%$, dan $40 \%$ ).

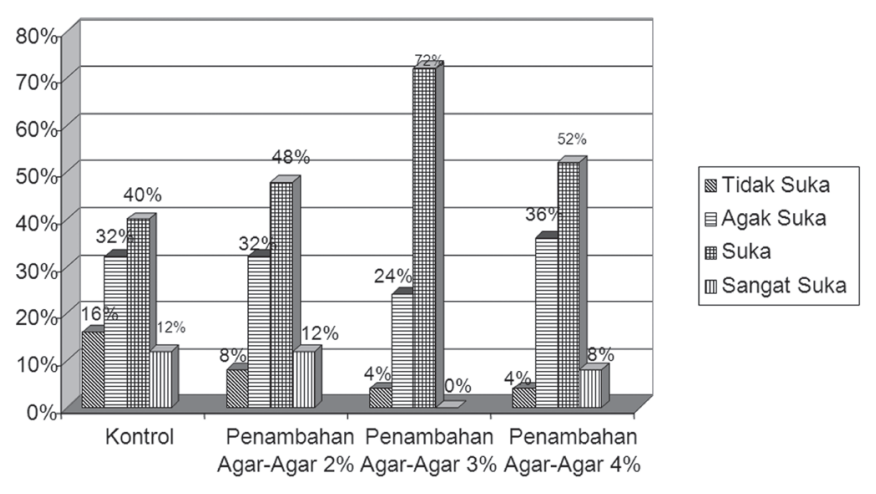

Gambar 4. Tingkat kesukaan panelis terhadap kekentalan susu tempe

Tabel 5. Analisis tingkat kesukaan panelis terhadap kekentalan susu tempe

\begin{tabular}{lcccc}
\hline \multicolumn{1}{c}{ Variabel } & Panelis & Rerata & F & P \\
\hline Tanpa penambahan agar- & 25 & 3,48 & & \\
agar (kontrol ) & & & & \\
Penambahan agar-agar 2\% & 25 & 3,64 & 0,342 & 0,795 \\
Penambahan agar-agar 3\% & 25 & 3,68 & & \\
Penambahan agar-agar 4\% & 25 & 3,64 & & \\
\hline
\end{tabular}

Pada Tabel 5, tingkat kesukaan panelis terhadap kekentalan susu tempe mempunyai skor antara 3,48 sampai dengan 3,68 . Skor tertinggi dimiliki oleh susu tempe dengan penambahan agar-agar 3\%, yang berarti panelis lebih menyukai kekentalan susu tempe dengan penambahan agar-agar $3 \%$ daripada kekentalan susu tempe lainnya. Hasil uji statistik menggunakan analisis anova menunjukkan bahwa $F$ hitung adalah 0,342 dengan $P$-value 0,795, dapat disimpulkan bahwa tidak ada pengaruh nyata penambahan agar-agar dengan berbagai konsentrasi terhadap daya terima kekentalan susu tempe. 


\section{Nilai gizi}

Secara klasik nilai gizi dari pangan adalah ikatan kimia yang terkandung pada makanan yang diperlukan tubuh untuk melakukan fungsinya, seperti menghasilkan energi, membangun, memelihara jaringan, dan mengatur prosesproses kehidupan. Untuk mengetahui nilai gizi, maka susu tempe dengan penambahan agar-agar $4 \%$ yang merupakan susu tempe dengan konsistensi emulsi paling stabil dilakukan analisis proksimat. Sedangkan untuk nilai energi dilakukan perhitungan menggunakan faktor dari Atwater dan kadar karbohidrat menggunakan perhitungan karbohidrat melalui selisih (Carbohydrates by difference).

Hasil analisis nilai gizi susu tempe dengan penambahan agar-agar 4\% kemudian dibandingkan dengan jenis susu lainnya. Untuk perbandingan mutu gizi dari susu tempe tersebut pada Tabel 6 ditampilkan komposisi nilai gizi per 100 gram susu tempe, susu sapi, dan ASI jenis matur.

Tabel 6. Nilai gizi susu tempe, susu kedelai, susu sapi dan air susu ibu per 100 gram

\begin{tabular}{lcccc}
\hline \multicolumn{1}{c}{ Nilai Gizi } & $\begin{array}{c}\text { Susu } \\
\text { tempe }\end{array}$ & $\begin{array}{c}\text { Susu* } \\
\text { kedelai }\end{array}$ & $\begin{array}{c}\text { Susu* } \\
\text { sapi }\end{array}$ & ASI* $^{*}$ \\
\hline Energi (Kalori) & 55,54 & 41 & 51 & 62,0 \\
Air (gram) & 86,23 & 87 & 88,33 & 88,6 \\
Protein (gram) & 2,14 & 3,50 & 3,2 & 1,40 \\
Lemak (gram) & 1,82 & 2,50 & 3,50 & 3,10 \\
Karbohidrat (gram) & 7,65 & 5,00 & 4,30 & 7,20 \\
Abu (\%) & 0,15 & - & - & - \\
Serat Kasar (\%) & 2,01 & - & - & - \\
\hline
\end{tabular}

Keterangan:

* Sumber: Direktorat Gizi Departemen Kesehatan RI (2003) (10)

Berdasarkan uji proksimat ternyata nilai gizi susu tempe tidak berbeda jauh dengan nilai gizi susu lainnya. Dengan kadar air yang relatif sama dapat diartikan bahwa keempat susu di atas mempunyai kepadatan gizi dan energi yang tidak jauh berbeda.

Melalui proses fermentasi, banyak zat gizi pada kedelai mengalami perubahan menjadi bersifat lebih larut dalam air dan mudah dicerna. Hampir separuh dari kandungan protein kedelai selama fermentasi dipecah menjadi produk yang lebih kecil dan larut dalam air seperti peptida dan asam-asam amino (13), sehingga seperti terlihat pada Tabel 6, kadar protein susu tempe sedikit lebih rendah daripada susu kedelai akan tetapi bila dibandingkan dengan kadar protein ASI masih lebih tinggi.

Banyak peneliti melaporkan, kadar lemak kedelai akan mengalami penurunan sedangkan asam lemak bebas mengalami peningkatan selama fermentasi. Lebih dari sepertiga lemak netral dari kedelai terhidrolisis oleh enzim lipase selama 3 hari fermentasi oleh Rhizopus oligosporus pada susu $37^{\circ} \mathrm{C}$. Peneliti lain juga melaporkan bahwa setelah 48 jam fermentasi dengan biakan Rhizopus oligosporus $20 \%$ lemak akan terhidrolisis (1). Seperti terlihat pada Tabel 6, lemak susu tempe paling rendah bila dibandingkan susu lainnya. Dengan kandungan lemak yang rendah maka susu tempe dapat dijadikan bagian dari terapi diet yang menyehatkan.

Perlakuan perendaman dan perebusan kedelai dalam pembuatan tempe menyebabkan pengurangan kandungan gula, yaitu stakhiosa, rafinosa dan sukrosa berturut-turut menjadi $51 \%, 48 \%$, dan $41 \%$ dari kadar awalnya (14). Penurunan kadar stakhiosa, rafinosa serta meningkatnya monosakarida pada tempe, mempunyai keuntungan selain memperbaiki nilai gizi, juga tidak menimbulkan gas. Penelitian lain membuktikan bahwa tempe kedelai yang dikonsumsi tidak dapat menimbulkan gas. Hasil penelitian tersebut menunjukkan koefisien daya cerna tempe adalah $86,1 \%$, sedangkan sebelum difermentasi daya cerna kedelai sekitar $42 \%$ (15). Namun seperti terlihat pada Tabel 6, nilai karbohidrat susu tempe ternyata lebih tinggi bila dibandingkan dengan nilai karbohidrat dari susu kedelai, hal ini dapat disebabkan peningkatan nilai karbohidrat susu tempe banyak dipengaruhi oleh penambahan gula pada waktu pemasakan susu tempe.

Dietary Fibre didefinisikan sebagai sisa serat yang tidak larut oleh etanol $80 \%$, yang di antaranya berupa protein yang tidak tercerna secara enzimatik dan fraksi hemiselulosa yang tidak larut oleh oksalat. Susu tempe merupakan sumber serat yang baik, seperti terlihat di Tabel 6, setiap $100 \mathrm{~g}$ susu tempe mengandung serat $2,01 \mathrm{~g}$. Sumber serat dari susu tempe, selain berasal dari miselium cendawan yang mengandung serat juga berasal dari agar-agar yang merupakan polisakarida dengan kandungan serat tinggi.

\section{KESIMPULAN DAN SARAN}

Berdasarkan hasil penelitian ini disimpulkan bahwa pengamatan visual dan pengujian viskositas menunjukkan semakin tinggi konsentrasi agar-agar yang ditambahkan, maka akan didapatkan kestabilan emulsi susu tempe yang semakin baik. Kestabilan susu tempe yang terbaik ditunjukkan pada susu tempe dengan penambahan agar-agar $4 \%$ dan kestabilan emulsi yang paling rendah ditunjukkan pada susu tempe tanpa penambahan agaragar (kontrol). Kemudian tidak ada pengaruh penambahan agar-agar dengan berbagai konsentrasi terhadap daya terima susu tempe.

Analisis uji proksimat pada susu tempe dengan penambahan agar-agar $4 \%$ sebagai susu tempe paling stabil yaitu setiap $100 \mathrm{~g}$ mempunyai kandungan energi 55,54 kKal dengan komposisi kadar air 86,23\%, kadar abu $0,15 \%$, kadar protein 2,14\%, kadar serat 2,01\%, kadar lemak 1,82\%, dan kadar karbohidrat 7,65\%.

Untuk meningkatkan citarasa susu tempe, maka dalam penyajian dapat ditambahkan perasa. Diperlukan analisis kandungan gizi susu tempe yang lebih spesifik, tidak sebatas analisis gizi proksimat kuantitatif tetapi juga 
kualitatif seperti bioavalaibilitas berupa protein, lemak, vitamin dan mineral dari susu tempe sehingga dapat digunakan sebagai pangan fungsional. Untuk menggali potensi susu tempe, perlu dilakukan penelitian lebih lanjut tentang pengaruh susu tempe terhadap aspek-aspek kesehatan, seperti pengaruh pemberian susu tempe terhadap penanggulangan Kurang Energi Protein (KEP) dan lama atau frekuensi diare, peningkatan albumin, perbaikan penyakit: kardiovaskuler, gastrohepato, nephrotic syndrom dan lain-lain.

\section{RUJUKAN}

1. Kasmidjo RB. Tempe mikrobiologi dan biokimia pengolahan serta pemanfaatannya. Yogyakarta: PAU Pangan dan Gizi: Universitas Gadjah Mada; 1990. 15-20, 49-61.

2. Astuti M, Meliala A, Dalais FS, Wahlqvist ML. Tempe, a nutritious and healthy food from Indonesia. Asia Pasific J Clin Nutr 2000; 9(4): 322-5.

3. Partawihardja S. Pengaruh suplementasi tempe terhadap kecepatan tumbuh pada penderita diare anak umur 6-24 bulan. Semarang: Universitas Diponegoro; 1990. 71-80.

4. Suryani I. Pengaruh pemberian formula bahan makanan campuran terhadap asupan makanan dan daya terima pada anak penderita diare umur 6-30 bulan. Buletin Nutrisia 2005; 6(2).

5. Soraya N. Rumput laut untuk kosmetik [serial online] 2005 [cited 2007 March] Avalaible from: http://www. pikiranrakyat.com/cetak/2005/1205/04/hikmah/lainnya02. htm.

6. De Man JM. Kimia makanan edisi kedua. Bandung: Institut Teknologi Bandung; 1997. 206-11, 299-313.

7. Susilowati A, Aspiyanto. Alternatif pati jagung termodifikasi sebagai pengental dan penstabil serta pengaruhnya terhadap kualitas susu tempe secara hidrolis enzimatik. Jakarta: Lembaga IImu Pengetahuan Indonesia; 2004.

8. Kartika B, Hastuti P, Supartono W. Pedoman uji inderawi bahan pangan, PAU pangan dan gizi. Yogyakarta: UGM; 1988. 2-8, 10-8, 31-43.

9. Khomsan A. Pangan dan gizi untuk kesehatan. Jakarta: Raja Grafindo Persada; 2003. 56, 147-9.

10. Heinnermen J. Direktorat Gizi Departemen Kesehatan $\mathrm{RI}$; Khasiat kedelai bagi kesehatan. Jakarta: Prestasi Pustakaraya; 2003.

11. Furqon. Statistik terapan untuk penelitian. Bogor: Alfabeta; 2004. 213-6.

12. Winarno FG. Tempe-peningkatan mutu dan statusnya di masyarakat. Simposium pemanfaatan tempe dalam peningkatan upaya kesehatan dan gizi. Jakarta: Departemen Kesehatan RI; 1985. 69-82.

13. Astuti M. Iron biovailability of traditional indonesia soybean tempe. Japan: Tokyo University of Agriculture; 1994. 12-4.

14. Cahyadi W. Kedelai khasiat dan teknologi. Jakarta: Bumi Aksara; 2007.

15. Karyadi D. Simposium pemanfaatan tempe dalam peningkatan upaya kesehatan dan gizi: Departemen Kesehatan RI; 1985. 20-8. 